\title{
Model-Based Design of Tailor-Made Biofuels
}

- Supporting Information -

\author{
Manuel Dahmen ${ }^{\dagger}$ and Wolfgang Marquardt*,,$\dagger$ \\ Aachener Verfahrenstechnik - Process Systems Engineering, RWTH Aachen University, \\ Turmstr. 46, 52064 Aachen, Germany \\ E-mail: w.marquardt@fz-juelich.de
}

\section{Data pretreatment and partitioning for QSPR modeling}

The DIPPR database ${ }^{1}$ has been utilized to tailor QSPR models for the prediction of fuel properties, solely based on information derived from the two-dimensional molecular graph. Data collected for the purpose of modeling have been restricted to compounds containing carbon, oxygen and hydrogen atoms only. Since molecular graphs with less than three carbon atoms shall not be considered as products by the structure generator, such small compounds have been excluded from the modeling datasets. Similar to Dahmen et al., ${ }^{2}$ only data being classified as "accepted" by DIPPR ${ }^{1}$ staff and exhibiting a relative error of $\leq 10 \%$ have been retrieved from the database. Nine-hundred zero- to two-dimensional molecular descriptors ${ }^{3}$ (blocks 1 to 10, 17 and 18 in DragonX version 1.4.4 ${ }^{4}$ ) have been calculated for each molecular structure. Constant and incomplete descriptor data have been dropped. All descriptor data have been scaled to unit-variance and zero mean. ${ }^{5,6}$

\footnotetext{
${ }^{*}$ To whom correspondence should be addressed

${ }^{\dagger}$ RWTH Aachen University

${ }^{\ddagger}$ Present address: Forschungszentrum Jülich GmbH, 52425 Jülich, Germany.
} 
Table 1: Pretreatment of datasets for QSPR modeling

\begin{tabular}{|c|c|c|c|c|c|c|c|}
\hline & $\begin{array}{l}\text { lower } \\
\text { heating } \\
\text { value } \\
\text { at } 298 \\
\text { K }\end{array}$ & $\begin{array}{l}\text { liquid } \\
\text { density } \\
\text { at } 298 \\
\mathrm{~K}\end{array}$ & $\begin{array}{l}\text { boiling } \\
\text { point }\end{array}$ & $\begin{array}{l}\text { melting } \\
\text { point }\end{array}$ & $\begin{array}{l}\text { enthalpy } \\
\text { of va- } \\
\text { poriza- } \\
\text { tion at } \\
298 \mathrm{~K}\end{array}$ & $\begin{array}{l}\text { surface } \\
\text { tension } \\
\text { at } 298 \\
\text { K }\end{array}$ & $\begin{array}{l}\text { dynamic } \\
\text { viscos- } \\
\text { ity at } \\
298 \mathrm{~K}\end{array}$ \\
\hline $\begin{array}{l}\text { no. of compounds re- } \\
\text { trieved from DIPPR } \\
\text { database }\end{array}$ & 971 & 707 & 977 & 954 & 487 & 573 & 473 \\
\hline $\begin{array}{l}\text { no. of compounds after } \\
\text { removal of property out- } \\
\text { liers }\end{array}$ & 967 & 707 & 977 & 953 & 484 & 573 & 469 \\
\hline $\begin{array}{l}\text { no. of compounds after } \\
\text { removal of PCA outliers }\end{array}$ & 932 & 676 & 942 & 914 & 480 & 558 & 459 \\
\hline $\begin{array}{l}\text { no. of descriptors (w/o } \\
\text { constant and incomplete } \\
\text { data) }\end{array}$ & 658 & 655 & 657 & 657 & 649 & 654 & 647 \\
\hline $\begin{array}{l}\text { no. of PCs needed to de- } \\
\text { scribe } 60 \% \text { of variation in } \\
\text { the descriptor data }\end{array}$ & 3 & 3 & 3 & 3 & 3 & 3 & 3 \\
\hline $\begin{array}{l}\text { compounds above } 95.0 \% \\
\text { Hotelling's } \mathrm{T}^{2} \text { threshold }\end{array}$ & $6.4 \%$ & $4.6 \%$ & $6.2 \%$ & $6.0 \%$ & $5.2 \%$ & $4.7 \%$ & $6.1 \%$ \\
\hline
\end{tabular}


Table 1 summarizes information on the data pre-treatment. Few property outliers, i.e., compounds exhibiting an unusual high or low property value, have been inspected and removed manually. Principal component analysis $(\mathrm{PCA})^{7,8}$ has been used to transform the descriptor data into a reduced space with uncorrelated coordinates. ${ }^{6,9}$ As can be seen from Table 1, three principal components (PCs) have been found to be sufficient to capture $60 \%$ of the variation in the descriptor data. In the PCA model, strong outliers, i.e., those compounds significantly leveraging the model due to a deviation from normality, were identified by Hotelling's $\mathrm{T}^{2}$ statistic. $^{6,9,10}$ If one or more strong outliers had been detected at $99.9 \%$ significance level, the compound exhibiting the highest $\mathrm{T}^{2}$ value had been removed and a new PCA model has been created. This procedure has been applied repeatedly until all outliers by this definition were excluded.

Table 2: Data partitioning into training and test sets: $d_{5 N T N}$ is the mean distance to the five nearest training neighbors (Euclidean distance in three-dimensional principal component space of the training data descriptors)

\begin{tabular}{l|l|l|l|l|l|l|l|l}
\hline & $\begin{array}{l}\text { size of } \\
\text { training } \\
\text { set }\end{array}$ & $\begin{array}{l}\text { size of } \\
\text { test set }\end{array}$ & $\begin{array}{l}d_{5 \mathrm{NTN}} \begin{array}{l}\text { of } \\
\text { training set } \\
\text { compounds }\end{array} \\
\text { mean }\end{array}$ & $\begin{array}{l}d_{5 \mathrm{NTN}} \\
\text { test } \\
\text { compounds }\end{array}$ & $\begin{array}{l}\text { of } \\
\text { set } \\
\text { mean }\end{array}$ & $\begin{array}{l}d_{5 \mathrm{NTN}, \mathrm{n}} \\
\text { normal- } \\
\text { ization } \\
\text { factor }\end{array}$ \\
\hline lower heating value & 792 & 140 & 2.6 & 16.2 & 4.4 & 14.0 & 6.2 \\
liquid density & 575 & 101 & 4.1 & 21.8 & 6.3 & 21.8 & 9.3 \\
normal boiling point & 802 & 140 & 2.5 & 11.0 & 4.2 & 19.3 & 5.9 \\
melting point & 778 & 136 & 2.7 & 14.7 & 4.2 & 12.1 & 6.5 \\
enthalpy of vaporization & 409 & 71 & 3.5 & 18.1 & 5.5 & 12.6 & 9.1 \\
surface tension & 474 & 84 & 3.2 & 19.2 & 5.2 & 15.6 & 7.8 \\
liquid viscosity & 390 & 69 & 3.7 & 14.1 & 4.9 & 13.2 & 9.0 \\
\hline
\end{tabular}

In addition, the PCA model has been used for data partitioning into training and test sets. Test sets have been utilized exclusively for assessing the predictive power of the QSPRs. ${ }^{11,12}$ To this end, a variant of stochastic cluster analysis ${ }^{13,14}$ has been implemented to select test set compounds such that they have a large Euclidean distance to each other in the PC space. This way, test set compounds cover the entire molecular domain. As can be seen from Table 
2 , the test sets contain about $15 \%$ of the total data available for modeling.

For applicability domain ${ }^{15,16}(\mathrm{AD})$ evaluation, the descriptor data of a novel compound are projected into the PC space of the training data. This allows for the computation of the average Euclidean distance to the five nearest training neighbors $d_{5 N T N}{ }^{16}$ This distance is then normalized with the help of the normalization factor $d_{5 N T N, n}$ of the specific QSPR model (cf. Table 2). If $d_{5 N T N} / d_{5 N T N, n} \leq 1$, the novel compound is located inside the AD. The normalization factor is defined as the $95 \%$ percentile of the $d_{5 N T N}$ values of all training compounds. ${ }^{16}$ As can be seen from Table 2, some test set compounds do not lie inside the model's AD. This is a result of the partitioning algorithm maximizing diversity for the test set. The chosen AD criterion is therefore rather restrictive.

\section{Exemplary encodings of molecular graphs}

Table 3 shows two exemplary encodings of molecular graphs. They follow the generic encoding scheme, which is depicted in Table 6 of the manuscript.

\section{Transformation rules for molecular structure generation}

The transformation rules implemented in the molecular structure generator are given in Tables 4 to 7 . The transformations are sorted by functional groups and have been derived based on the reviews of catalytic strategies for the production of biofuels prepared by Corma et al., ${ }^{17}$ Alonso et al., ${ }^{18}$ Serrano-Ruiz et al., ${ }^{19,20}$ Lange et al. ${ }^{21,22}$ and Climent et al. ${ }^{23}$ More-

over, the works of Julis and Leitner ${ }^{24}$ and Luska et al. ${ }^{25}$ have motivated the inclusion of the carbon-carbon coupling scheme based on aldol condensation. 
Table 3: Furfural and itaconic acid encoded by the scheme depicted in Table 6 of the manuscript

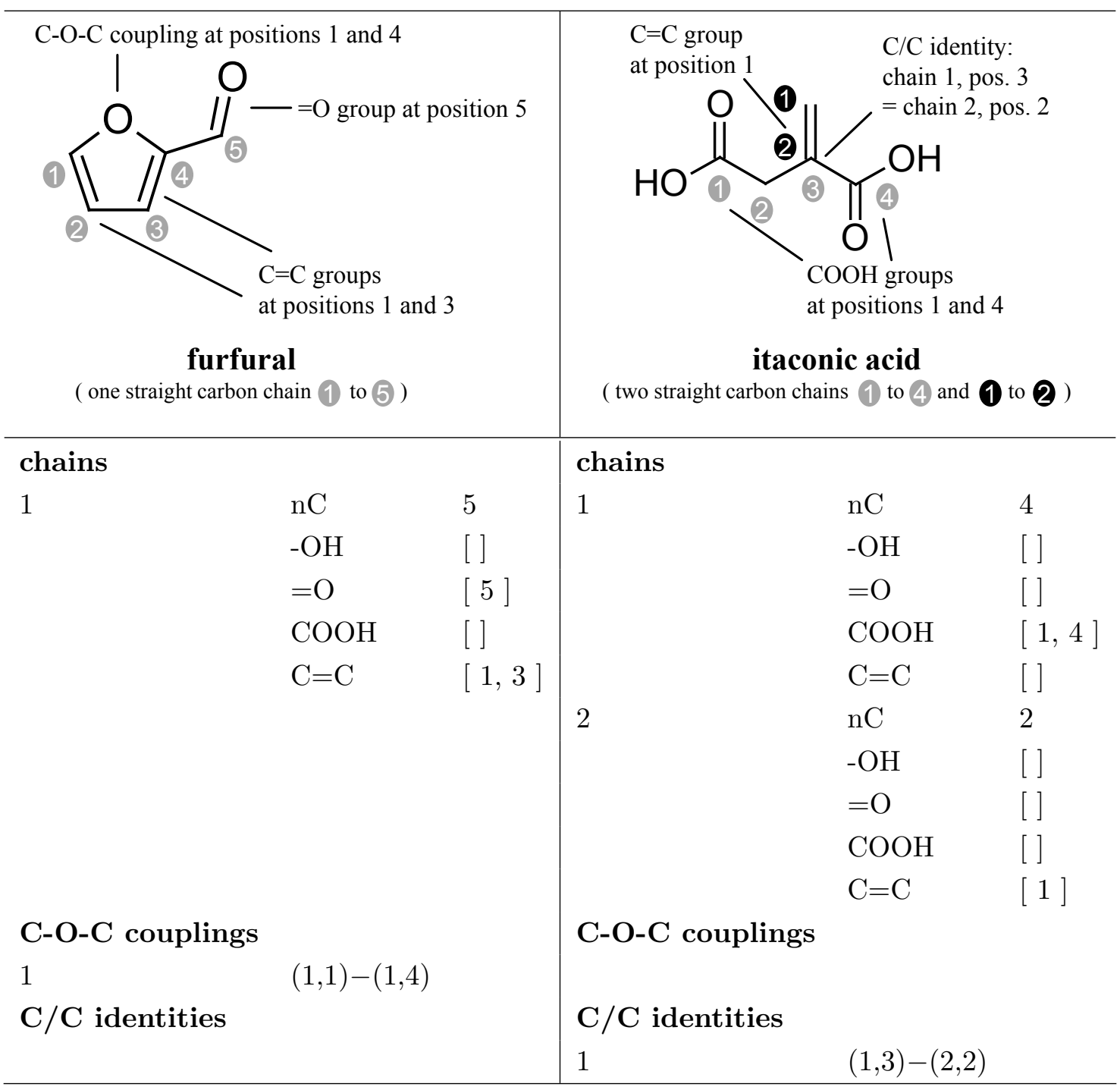


Table 4: Refunctionalization: Single-molecule transformations classified by target structural groups

\begin{tabular}{|c|c|}
\hline \multicolumn{2}{|r|}{$=\mathrm{O}$ group } \\
\hline$\overbrace{\text { example: }}^{\stackrel{+\mathrm{H}_{2}}{\longrightarrow}} \underset{\text { butanone } \rightarrow \text { 2-butanol }}{\longrightarrow}$ & $\begin{array}{l}\text { hydrogenation of ketones/aldehydes to alcohols } \\
\text { 1. } \mathrm{C}^{*} \text { is a carbon carrying an }=\mathrm{O} \text { group } \\
\text { 2. } \mathrm{C}^{*} \text { is not part of an oxygen coupling }\left(\mathrm{C}^{*}-\mathrm{O}-\mathrm{C}^{* *}\right) \text {, i.e., it } \\
\text { is not part of an acyclic/cyclic ester or anhydride } \\
\text { 3. replace }=\mathrm{O} \text { group with }-\mathrm{OH} \text { group at } \mathrm{C}^{*}\left[+\mathbf{H}_{2}\right]\end{array}$ \\
\hline \multicolumn{2}{|r|}{ COOH group } \\
\hline $\begin{array}{l}\underset{\mathrm{OH}}{\stackrel{\mathrm{O}}{\mathrm{H}_{2} \mathrm{O}} \underset{\mathrm{H}_{2}}{\longrightarrow}} \underset{\text { example: }}{\mathrm{O}} \\
\text { formic acid } \rightarrow \text { ethanal }\end{array}$ & $\begin{array}{l}\text { reduction of carboxylic acid to aldehyde } \\
\text { 1. } \mathrm{C}^{*} \text { is a carbon member of a } \mathrm{COOH} \text { group } \\
\text { 2. transform } \mathrm{C}^{*} \text { to carry an }=\mathrm{O} \text { group instead of being part of } \\
\text { a COOH group }\left[+\mathbf{H}_{2},-\mathbf{H}_{2} \mathbf{O}\right]\end{array}$ \\
\hline $\begin{array}{l}\text { maleic acid } \rightarrow \text { maleic } \\
\quad \text { anhydride }\end{array}$ & $\begin{array}{l}\text { intramolecular condensation of dicarboxylic acid to } \\
\text { cyclic anhydride } \\
\text { 1. } \mathrm{C}^{*} \text { and } \mathrm{C}^{* *} \text { are two carbons in the same molecule, that } \\
\text { a. are parts of } \mathrm{COOH} \text { groups } \\
\text { b. are not identical }\left(\mathrm{C}^{*} \neq \mathrm{C}^{* *}\right) \\
\text { c. have at least } x \text { carbons/oxygens inbetween (no rings smaller } \\
\text { than } x+3 \text { ) } \\
\text { d. have a maximum of } y \text { carbons/oxygens inbetween (no rings } \\
\text { larger then } y+3 \text { ) } \\
\text { e. have only one existing path between each other (not part } \\
\text { of an existing ring) OR have two existing paths between each } \\
\text { other, but one path is a subset of the other path (allows for the } \\
\text { formation of two rings attached to each other) } \\
\text { 2. take away COOH groups from } \mathrm{C}^{*} \text { and } \mathrm{C}^{* *} \\
\text { 3. make a C-O-C coupling between } \mathrm{C}^{*} \text { and } \mathrm{C}^{* *} \text {, i.e., } \\
\mathrm{C}^{*}-\mathrm{O}-\mathrm{C}^{* *} \text { (ring formation) } \\
\text { 4. place }=\mathrm{O} \text { groups at } \mathrm{C}^{*} \text { and } \mathrm{C}^{* *}\left[-\mathrm{H}_{2} \mathrm{O}\right]\end{array}$ \\
\hline
\end{tabular}


Table 4: Refunctionalization: Single-molecule transformations classified by target structural groups (continued)

\begin{tabular}{|c|c|}
\hline \multicolumn{2}{|c|}{ cyclic $-\mathrm{O}-$ group (ester, ether, anhydride) } \\
\hline$\underset{\substack{\text { example: } \\
\text { tetrahydrofuran } \rightarrow \text { 1-butanol }}}{\stackrel{+\mathrm{H}_{2}}{\longrightarrow}}$ & 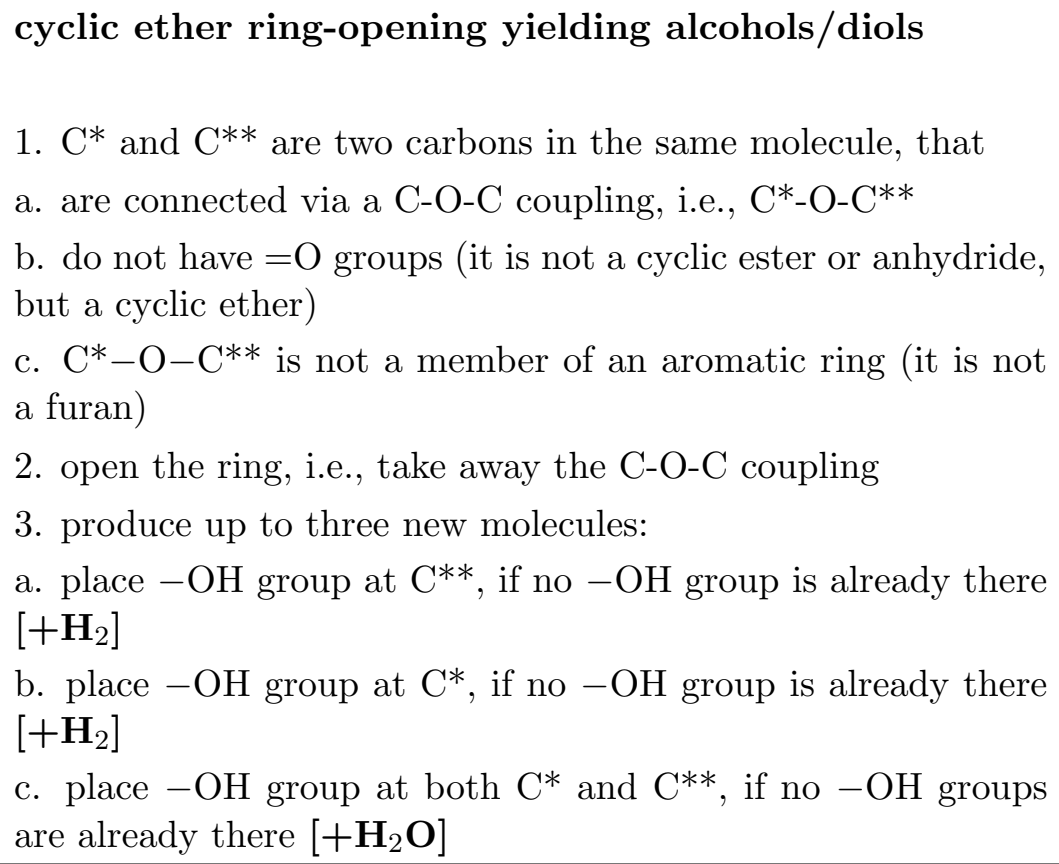 \\
\hline $\begin{array}{l}\underset{\text { example: }}{\longrightarrow} \stackrel{+\mathrm{H}_{2}}{\longrightarrow} \underset{\text {-valerolactone } \rightarrow}{\longrightarrow} \rightarrow \\
\text { acid }\end{array}$ & $\begin{array}{l}\text { cyclic ester ring-opening yielding an acid } \\
\text { 1. } \mathrm{C}^{*} \text { and } \mathrm{C}^{* *} \text { are two carbons in the same molecule, that } \\
\text { a. are connected via a } \mathrm{C}-\mathrm{O}-\mathrm{C} \text { coupling, i.e., } \mathrm{C}^{*}-\mathrm{O}-\mathrm{C}^{* *} \\
\text { b. } \mathrm{C}^{*} \text { carries an }=\mathrm{O} \text { group, but } \mathrm{C}^{* *} \text { does not carry an }=\mathrm{O} \\
\text { group (cyclic ester) } \\
\text { 2. open the ring, i.e., take away the } \mathrm{C}-\mathrm{O}-\mathrm{C} \text { coupling } \\
\text { 3. remove the }=\mathrm{O} \text { group from } \mathrm{C}^{*} \\
\text { 4. make } \mathrm{C}^{*} \text { part of a } \mathrm{COOH} \text { group }\left[+\mathbf{H}_{2}\right]\end{array}$ \\
\hline $\begin{array}{c}\stackrel{\mathrm{O}}{\stackrel{+\mathrm{H}_{2}}{\longrightarrow}} \mathrm{O}^{2} \mathrm{OH} \\
\text { example: } \\
\text { cleavage of maleic anhydride }\end{array}$ & $\begin{array}{l}\text { cyclic anhydride ring-opening } \\
\text { 1. } \mathrm{C}^{*} \text { and } \mathrm{C}^{* *} \text { are two carbons in the same molecule, that } \\
\text { a. are connected via a } \mathrm{C}-\mathrm{O}-\mathrm{C} \text { coupling, i.e., } \mathrm{C}^{*}-\mathrm{O}-\mathrm{C}^{* *} \\
\text { b. both } \mathrm{C}^{*} \text { and } \mathrm{C}^{* *} \text { carry an }=\mathrm{O} \text { group (cyclic anhydride) } \\
\text { 2. open the ring, i.e., take away the } \mathrm{C}-\mathrm{O}-\mathrm{C} \text { coupling } \\
\text { 3. remove the }=\mathrm{O} \text { groups from } \mathrm{C}^{*} \text { and } \mathrm{C}^{* *} \\
\text { 4. produce two new molecules: } \\
\text { a. make } \mathrm{C}^{*} \text { part of a COOH group, add }=\mathrm{O} \text { group at } \mathrm{C}^{* *} \\
{\left[+\mathbf{H}_{2} \text { ] }\right.} \\
\text { b. make } \mathrm{C}^{* *} \text { part of a } \mathrm{COOH} \text { group, add }=\mathrm{O} \text { group at } \mathrm{C}^{*} \\
{\left[+\mathbf{H}_{2}\right]}\end{array}$ \\
\hline
\end{tabular}


Table 4: Refunctionalization: Single-molecule transformations classified by target structural groups (continued)

\section{$-\mathrm{OH}$ group}

\begin{tabular}{|c|c|}
\hline $\begin{array}{l}\underset{-\mathrm{H}_{2} \mathrm{O}}{\longrightarrow} \underset{\text { example: }}{\stackrel{+\mathrm{H}_{2}}{\longrightarrow}} \backslash \\
\text { 2-butanol } \rightarrow \text { butane }\end{array}$ & $\begin{array}{l}\text { reduction of alcohol to alkane } \\
\text { 1. } \mathrm{C}^{*} \text { is a carbon carrying an }-\mathrm{OH} \text { group } \\
\text { 2. remove the }-\mathrm{OH} \text { group from } \mathrm{C}^{*}\left[+\mathbf{H}_{2},-\mathbf{H}_{2} \mathbf{O}\right]\end{array}$ \\
\hline $\begin{array}{l}\underset{-\mathrm{H}_{2} \mathrm{O}}{\longrightarrow} \\
\text { example: } \\
\text { 1,4-butanediol } \rightarrow \\
\text { tetrahydrofuran }\end{array}$ & $\begin{array}{l}\text { cyclodehydration of diols to cyclic ether } \\
\text { (self-etherification) } \\
\text { 1. } \mathrm{C}^{*} \text { and } \mathrm{C}^{* *} \text { are two carbons in the same molecule, that } \\
\text { a. both carry an }-\mathrm{OH} \text { group } \\
\text { b. are not identical }\left(\mathrm{C}^{*} \neq \mathrm{C}^{* *}\right) \\
\text { c. have at least } x \text { carbons/oxygens inbetween (no rings smaller } \\
\text { than } x+3 \text { ) } \\
\text { d. have a maximum of } y \text { carbons/oxygens inbetween (no rings } \\
\text { larger then } y+3 \text { ) } \\
\text { e. have only one existing path between each other (not part } \\
\text { of an existing ring) OR have two existing paths between each } \\
\text { other, but one path is a subset of the other path (allows for the } \\
\text { formation of two rings attached to each other) } \\
\text { 2. remove the }-\mathrm{OH} \text { groups from } \mathrm{C}^{*} \text { and } \mathrm{C}^{* *} \\
\text { 3. make a C-O-C coupling between } \mathrm{C}^{*} \text { and } \mathrm{C}^{* *} \text {, i.e., } \\
\mathrm{C}^{*}-\mathrm{O}-\mathrm{C}^{* *}\left[-\mathrm{H}_{2} \mathbf{O}\right]\end{array}$ \\
\hline $\begin{array}{l}\text { example: } \\
\text { 2-butanol } \rightarrow \text { butanone }\end{array}$ & $\begin{array}{l}\text { dehydrogenation of alcohols to aldehydes/ketones } \\
\text { 1. } \mathrm{C}^{*} \text { carries an }-\mathrm{OH} \text { group } \\
\text { 2. } \mathrm{C}^{*} \text { carries at least one hydrogen atom } \\
\text { 3. } \mathrm{C}^{*} \text { has no double bond } \\
\text { 4. replace }-\mathrm{OH} \text { group by }=\mathrm{O} \text { group }\left[-\mathbf{H}_{2}\right]\end{array}$ \\
\hline
\end{tabular}


Table 4: Refunctionalization: Single-molecule transformations classified by target structural groups (continued)

\begin{tabular}{|c|c|}
\hline \multicolumn{2}{|c|}{$-\mathrm{OH}$ group together with $\mathrm{COOH}$ group } \\
\hline $\begin{array}{l}\stackrel{\mathrm{HO}}{\longrightarrow} \underset{\mathrm{OH}}{\longrightarrow} \stackrel{\mathrm{O}}{\longrightarrow} \mathrm{O}_{2} \mathrm{O} \\
\text { example: } \\
\text { formation of a lactone }\end{array}$ & $\begin{array}{l}\text { self-esterification (of carboxylic acid and alcohol } \\
\text { groups) } \\
\text { 1. } \mathrm{C}^{*} \text { and } \mathrm{C}^{* *} \text { are two carbons in the same molecule and } \\
\text { a. } \mathrm{C}^{*} \text { and } \mathrm{C}^{* *} \text { are not identical }\left(\mathrm{C}^{*} \neq \mathrm{C}^{* *}\right) \\
\text { b. } \mathrm{C}^{*} \text { carries an }-\mathrm{OH} \text { group } \\
\text { c. } \mathrm{C}^{* *} \text { is part of a COOH group } \\
\text { d. } \mathrm{C}^{*} \text { and } \mathrm{C}^{* *} \text { have at least } x \text { carbons/oxygens inbetween (no } \\
\text { rings smaller than } x+3 \text { ) } \\
\text { e. } \mathrm{C}^{*} \text { and } \mathrm{C}^{* *} \text { have a maximum of } y \text { carbons/oxygens inbe- } \\
\text { tween (no rings larger than } y+3 \text { ) } \\
\text { f. } \mathrm{C}^{*} \text { and } \mathrm{C}^{* *} \text { have only one existing path between each other } \\
\text { (not part of an existing ring) OR have two existing paths be- } \\
\text { tween each other, but one path is a subset of the other path } \\
\text { (allows for formation of two rings attached to each other) } \\
\text { 2. remove the -OH group from } \mathrm{C}^{*} \text { and remove the acid group } \\
\text { from } \mathrm{C}^{* *} \\
\text { 3. make a C-O-C coupling between } \mathrm{C}^{*} \text { and } \mathrm{C}^{* *} \text {, i.e., } \\
\mathrm{C}^{*}-\mathrm{O}-\mathrm{C}^{* *} \\
4 . \text { introduce a }=\mathrm{O} \text { group at } \mathrm{C}^{* *} \text { to complete the cyclic ester } \\
\text { [-H } \mathrm{H}_{2} \mathrm{O} \text { ] }\end{array}$ \\
\hline & $\mathrm{C}=\mathrm{C}$ group \\
\hline $\begin{array}{c}\text { example: } \\
\text { 2-butene } \rightarrow \text { butane }\end{array}$ & $\begin{array}{l}\text { hydrogenation of carbon-carbon double bond } \\
\text { 1. } \mathrm{C}^{*} \text { and } \mathrm{C}^{* *} \text { are connected by a } \mathrm{C}=\mathrm{C} \text { double bond }\left(\mathrm{C}^{*}=\mathrm{C}^{* *}\right) \\
\text { 2. } \mathrm{C}^{*}=\mathrm{C}^{* *} \text { is not a member of an aromatic ring } \\
\text { 3. replace this } \mathrm{C}=\mathrm{C} \text { double-bond by a } \mathrm{C}-\mathrm{C} \text { single-bond, i.e. } \\
\mathrm{C}^{*}-\mathrm{C}^{* *}\left[+\mathbf{H}_{2}\right]\end{array}$ \\
\hline
\end{tabular}


Table 4: Refunctionalization: Single-molecule transformations classified by target structural groups (continued)

\begin{tabular}{|c|c|}
\hline \multicolumn{2}{|r|}{ furan group } \\
\hline $\begin{array}{l}\stackrel{+\mathrm{H}_{2} \mathrm{O}}{\longrightarrow} \underset{\text { example: }}{\longrightarrow} \\
\text { cleavage of furan }\end{array}$ & $\begin{array}{l}\text { furan ring-opening yielding aldehydes/ketones } \\
\text { 1. furan ring, i.e., } \mathrm{C}^{*}=\mathrm{C}^{* *}-\mathrm{C}^{* * *}=\mathrm{C}^{* * * *} \text { and a } \mathrm{C}-\mathrm{O}-\mathrm{C} \text { cou- } \\
\text { pling of } \mathrm{C}^{*} \text { and } \mathrm{C}^{* * * *} \\
\text { 2. no }-\mathrm{OH} \text { groups attached to } \mathrm{C}^{*} \text { and } / \text { or } \mathrm{C}^{* * * *} \\
\text { 3. change } \mathrm{C}^{*}=\mathrm{C}^{* *} \text { to } \mathrm{C}^{*}-\mathrm{C}^{* *} \\
\text { 4. change } \mathrm{C}^{* * *}=\mathrm{C}^{* * * *} \text { to } \mathrm{C}^{* * *}-\mathrm{C}^{* * * *} \\
\text { 5. remove } \mathrm{C}-\mathrm{O}-\mathrm{C} \text { coupling of } \mathrm{C}^{*} \text { and } \mathrm{C}^{* * * *} \\
\text { 5. place }=\mathrm{O} \text { groups at } \mathrm{C}^{*} \text { and } \mathrm{C}^{* *}\left[+\mathrm{H}_{2} \mathrm{O}\right]\end{array}$ \\
\hline $\begin{array}{c}\text { example: } \\
\text { furan } \rightarrow \text { tetrahydrofuran }\end{array}$ & $\begin{array}{l}\text { hydrogenation of furan yielding tetrahydrofuran } \\
\text { 1. furan ring, i.e., } \mathrm{C}^{*}=\mathrm{C}^{* *}-\mathrm{C}^{* * *}=\mathrm{C}^{* * * *} \text { and a } \mathrm{C}-\mathrm{O}-\mathrm{C} \text { cou- } \\
\text { pling of } \mathrm{C}^{*} \text { and } \mathrm{C}^{* * * *} \\
\text { 2. remove double-bonds } \mathrm{C}^{*}=\mathrm{C}^{* *} \text { and } \mathrm{C}^{* * *}=\mathrm{C}^{* * * *}\left[+\mathbf{2} \mathbf{H}_{2}\right]\end{array}$ \\
\hline
\end{tabular}

Table 5: Aggregation: $\mathbf{C}-\mathbf{C}$ coupling of two molecules via aldol condensation<smiles>[R]C(=O)[CH]O[C@H](C)C([R2])C([R2])C([R])[R]</smiles>

1. $\mathrm{C}^{*}$ is a carbon in molecule $\mathrm{M} 1$, that

a. carries an $=\mathrm{O}$ group

b. is no member of a ring

c. has a single-bonded carbon neighbor $\mathrm{C}^{* * *}$ carrying at least two hydrogen atoms

d. $\mathrm{C}^{* * *}$ is not bonded to an oxygen atom

2. $\mathrm{C}^{* *}$ is a carbon in molecule $\mathrm{M} 2$

a. carrying an $=\mathrm{O}$ group

b. is no member of a ring

3. remove $=\mathrm{O}$ group from $\mathrm{C}^{* *}$

4. make a $\mathrm{C}-\mathrm{C}$ bond between $\mathrm{C}^{* *}$ and $\mathrm{C}^{* * *}$ by introducing two $\mathrm{C} / \mathrm{C}$ identities involving a newly created auxiliary chain consisting of two carbons $\left[+\mathbf{H}_{2}-\mathbf{H}_{2} \mathbf{O}\right]$ 
Table 6: Aggregation: Special cases of $\mathbf{C}-\mathbf{C}$ coupling of two molecules via aldol condensation

chain-lengthening aldol condensation

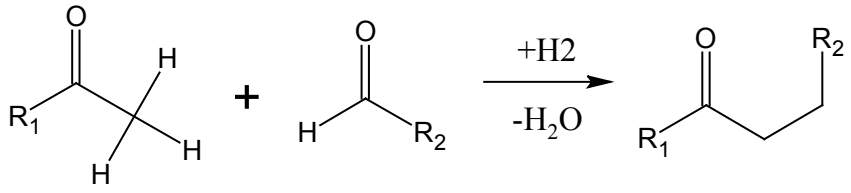

1. $\mathrm{C}^{*}$ is a carbon in molecule $\mathrm{M} 1$, that

a. carries an $=\mathrm{O}$ group

b. is no member of a ring

c. has a single-bonded carbon neighbor $\mathrm{C}^{* * *}$ carrying three hydrogen atoms

2. $\mathrm{C}^{* *}$ is a carbon in molecule M2

a. carrying an aldehyde group, i.e., an $=\mathrm{O}$ group at the end of the chain

b. is no member of a ring

3. remove the $=\mathrm{O}$ group from $\mathrm{C}^{* *}$

4. make a $\mathrm{C}-\mathrm{C}$ bond between $\mathrm{C}^{* *}$ and $\mathrm{C}^{* * *}$ by introducing two $\mathrm{C} / \mathrm{C}$ identities involving a newly created auxiliary chain consisting of two carbons $\left[+\mathbf{H}_{2}-\mathbf{H}_{2} \mathbf{O}\right]$

branch-inducing aldol condensation

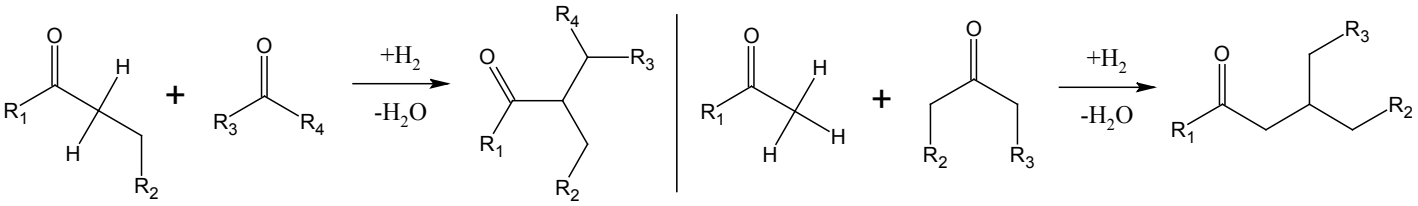

EITHER

1. $\mathrm{C}^{*}$ is a carbon in molecule $\mathrm{M} 1$, that

a. carries an $=\mathrm{O}$ group

b. is no member of a ring

c. has a single-bonded carbon neighbor $\mathrm{C}^{* * *}$

2. the carbon $\mathrm{C}^{* * *}$

a. carries two hydrogen atoms

b. has another single-bonded carbon neighbor

3. $\mathrm{C}^{* *}$ is a carbon in molecule $\mathrm{M} 2$, that

a. carries an $=\mathrm{O}$ group

b. is no member of a ring

OR

1. $\mathrm{C}^{*}$ is a carbon in molecule $\mathrm{M} 1$, that

a. carries an $=\mathrm{O}$ group

b. is no member of a ring

c. has a single-bonded carbon neighbor $\mathrm{C}^{* * *}$ carrying three hydrogen atoms

2. $\mathrm{C}^{* *}$ is a carbon in molecule $\mathrm{M} 2$, that

a. carries a ketone group, i.e., an $=\mathrm{O}$ group not located at the chain end

b. is no member of a ring

THEN

1. remove $=\mathrm{O}$ group from $\mathrm{C}^{* *}$

2. make a $\mathrm{C}-\mathrm{C}$ bond between $\mathrm{C}^{* *}$ and $\mathrm{C}^{* * *}$ by introducing two $\mathrm{C} / \mathrm{C}$ identities involving a newly created auxiliary chain consisting of two carbons $\left[+\mathbf{H}_{2}-\mathbf{H}_{2} \mathbf{O}\right]$ 
Table 7: Aggregation: $\mathbf{C}-\mathbf{O}-\mathbf{C}$ coupling of two molecules via etherification/esterification

etherification of alcohols

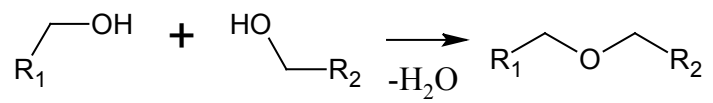

1. $\mathrm{C}^{*}$ is a carbon carrying an $-\mathrm{OH}$ group in molecule $\mathrm{M} 1$

2. $\mathrm{C}^{* *}$ is a carbon carrying an $-\mathrm{OH}$ group in molecule $\mathrm{M} 2$

3. remove $-\mathrm{OH}$ group from $\mathrm{C}^{*}$

4. remove $-\mathrm{OH}$ group from $\mathrm{C}^{* *}$

5. make a $\mathrm{C}-\mathrm{O}-\mathrm{C}$ coupling of $\mathrm{C}^{*}$ and $\mathrm{C}^{* *}\left[-\mathbf{H}_{2} \mathbf{O}\right]$

note: the alcohols do not have to be terminal alcohols

esterification of alcohol and carboxylic acid

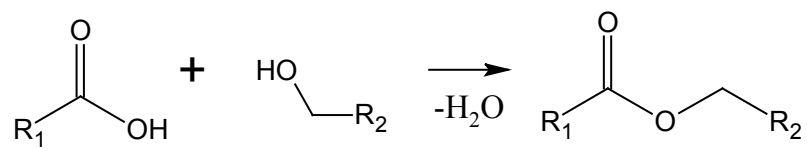

1. $\mathrm{C}^{*}$ is a carbon carrying an $-\mathrm{OH}$ group in molecule $\mathrm{M} 1$

2. carbon $\mathrm{C}^{* *}$ is a part of a $\mathrm{COOH}$ group in molecule $\mathrm{M} 2$

3. remove $-\mathrm{OH}$ group from $\mathrm{C}^{*}$

4. transform $\mathrm{COOH}$ group at $\mathrm{C}^{* *}$ to $=\mathrm{O}$ group at $\mathrm{C}^{* *}$

5. make a $\mathrm{C}-\mathrm{O}-\mathrm{C}$ coupling of $\mathrm{C}^{*}$ and $\mathrm{C}^{* *}\left[-\mathbf{H}_{2} \mathbf{O}\right]$

note: the alcohol does not have to be a terminal alcohol 


\section{Acknowledgement}

This work was performed as part of the Cluster of Excellence Tailor-Made Fuels from Biomass, which is funded by the Excellence Initiative by the German federal and state governments to promote science and research at German universities.

The authors thank Juan Jose Victoria Villeda for fruitful discussions on the model-based fuel design approach, in particular with regard to the formalization of refunctionalization patterns, as well as for supplying implementations of Morgan's algorithm and SMILES import/export routines.

The authors also want to thank Stefanie Mersmann (Institute of Organic Chemistry, RWTH Aachen University) and Jürgen Klankermayer (Institut für Technische und Makromolekulare Chemie, RWTH Aachen University) for their advice on the chemical feasibility of specific refunctionalizations.

Finally, the authors thank Florian Kremer, Andreas Janssen, Benedikt Heuser, Fabian Hoppe and Stefan Pischinger (Institute for Combustion Engines, RWTH Aachen University) for their advice on desired fuel properties and for the regular exchange on fuel candidates and fuel requirements.

\section{References}

(1) DIPPR 801 Database version 6.0.3, Design Institute for Physical Properties (DIPPR), American Institute of Chemical Engineers (AIChE), USA. 2012; http://www.aiche. org/dippr.

(2) Dahmen, M.; Hechinger, M.; Villeda, J. V.; Marquardt, W. Towards model-based identification of biofuels for compression ignition engines. SAE International Journal of Fuels and Lubricants 2012, 5, 990-1003.

(3) Todeschini, R.; Consonni, V. Handbook of Molecular Descriptors; Wiley-VCH Verlag GmbH, Weinheim, Germany, 2008. 
(4) Todeschini, R.; Consonni, V.; Mauri, A.; Pavan, M. DragonX version 1.4, Talete srl, Milan, Italy. 2009.

(5) Wold, S.; Sjöström, M.; Eriksson, L. PLS-regression: A basic tool of chemometrics. Chemometrics and Intelligent Laboratory Systems 2001, 58, 109-130.

(6) Eriksson, L.; Kettaneh-Wold, N.; Trygg, J.; Wikström, C.; Wold, S. Multi-and Megavariate Data Analysis: Part I: Basic Principles and Applications; Umetrics AB, Umea, Sweden, 2006.

(7) Wold, S.; Esbensen, K.; Geladi, P. Principal component analysis. Chemometrics and Intelligent Laboratory Systems 1987, 2, 37-52.

(8) Jolliffe, I. T. Principal Component Analysis - Second Edition; Springer, New York, 2002.

(9) Eriksson, L.; Andersson, P. L.; Johansson, E.; Tysklind, M. Megavariate analysis of environmental QSAR data. Part I - A basic framework founded on principal component analysis (PCA), partial least squares (PLS), and statistical molecular design (SMD). Molecular Diversity 2006, 10, 169-186.

(10) Wikström, C.; Albano, C.; Eriksson, L.; Fridén, H.; Johansson, E.; Nordahl, A.; Rännar, S.; Sandberg, M.; Kettaneh-Wold, N.; Wold, S. Multivariate process and quality monitoring applied to an electrolysis process: Part I. Process supervision with multivariate control charts. Chemometrics and Intelligent Laboratory Systems 1998, 42, 221-231.

(11) Tropsha, A. Best practices for QSAR model development, validation, and exploitation. Molecular Informatics 2010, 29, 476-488.

(12) Roy, K. On some aspects of validation of predictive quantitative structure-activity relationship models. Expert Opinion on Drug Discovery 2007, 2, 1567-1577. 
(13) Reynolds, C. H.; Druker, R.; Pfahler, L. B. Lead discovery using stochastic cluster analysis (SCA): a new method for clustering structurally similar compounds. Journal of Chemical Information and Computer Sciences 1998, 38, 305-312.

(14) Tropsha, A.; Golbraikh, A. In Handbook of Chemoinformatics Algorithms; Faulon, J.L., Bender, A., Eds.; Chapman and Hall/CRC Press, Boca Raton, FL, USA, 2010; Chapter Predictive Quantitative Structure-Activity Modeling.

(15) Jaworska, J.; Nikolova-Jeliazkova, N.; Aldenberg, T. QSAR applicabilty domain estimation by projection of the training set descriptor space: A review. Alternatives to Laboratory Animals: ATLA 2005, 33, 445-459.

(16) Weaver, S.; Gleeson, M. P. The importance of the domain of applicability in QSAR modeling. Journal of Molecular Graphics and Modelling 2008, 26, 1315-1326.

(17) Corma, A.; Iborra, S.; Velty, A. Chemical routes for the transformation of biomass into chemicals. Chemical Reviews 2007, 107, 2411-2502.

(18) Alonso, D. M.; Bond, J. Q.; Dumesic, J. A. Catalytic conversion of biomass to biofuels. Green Chemistry 2010, 12, 1493-1513.

(19) Serrano-Ruiz, J. C.; Luque, R.; Sepúlveda-Escribano, A. Transformations of biomassderived platform molecules: From high added-value chemicals to fuels via aqueousphase processing. Chemical Society Reviews 2011, 40, 5266-5281.

(20) Serrano-Ruiz, J. C.; Dumesic, J. A. Catalytic routes for the conversion of biomass into liquid hydrocarbon transportation fuels. Energy $\mathcal{E}$ Environmental Science 2011, 4, 83-99.

(21) Lange, J.-P.; van der Heide, E.; van Buijtenen, J.; Price, R. Furfural - A promising platform for lignocellulosic biofuels. ChemSusChem 2012, 5, 150-166. 
(22) Lange, J.-P.; Price, R.; Ayoub, P. M.; Louis, J.; Petrus, L.; Clarke, L.; Gosselink, H. Valeric biofuels: A platform of cellulosic transportation fuels. Angewandte Chemie International Edition 2010, 49, 4479-4483.

(23) Climent, M. J.; Corma, A.; Iborra, S. Conversion of biomass platform molecules into fuel additives and liquid hydrocarbon fuels. Green Chemistry 2014, 16, 516-547.

(24) Julis, J.; Leitner, W. Synthesis of 1-octanol and 1,1-dioctyl ether from biomass-derived platform chemicals. Angewandte Chemie International Edition 2012, 51, 8615-8619.

(25) Luska, K. L.; Julis, J.; Stavitski, E.; Zakharov, D. N.; Adams, A.; Leitner, W. Bifunctional nanoparticle-SILP catalysts (NPs@ SILP) for the selective deoxygenation of biomass substrates. Chemical Science 2014, 5, 4895-4905. 